\title{
Chira Csongor
}

\section{A digitális kompetencia keretrendszerei és a pedagógusok digitális kompetenciája}

\section{Bevezetés}

Az Európai Parlament és a Tanács az egész életen át tartó tanuláshoz szükséges kulcskompetenciákról szóló ajánlásának 2006-os publikálása óta a köznevelést meghatározó alapdokumentumok, tantervek és kutatások központi fogalma is a kompetencia lett.

Ezen kulcskompetenciák közé tartozik a digitális kompetencia is, amelynek definiálására több kísérlet is történt az elmúlt években. A téma vizsgálatának hazai aktualitását igazolja az is, hogy 2016-ban a köznevelési, a szakképzési, a felsőoktatási és a felnőttképzési rendszer digitális átalakitásáról és Magyarország Digitális Oktatási Stratégiájáról is született kormányrendelet (Digitális Oktatási Stratégia, 2016.), amiben szintén markánsan van jelen a digitális kompetencia fejlesztésének szükségessége.

A definiálás mellett még több tanulmány és kutatás is foglalkozik a kompetencia mérésével, annak fejlesztési lehetőségeivel, ezek között azonban igen bizonytalan a pedagógusok helyzete, ezért a következő oldalakon a digitális kompetencia nemzetközi és hazai keretrendszereinek bemutatása után a pedagógusok számára szükséges készségek feltárása olvasható. 


\section{A digitális kompetencia fogalma és keretrendszerei}

\subsection{Európai Unió}

2000 márciusában az Európai Tanács új stratégiai célt határozott meg az Európai Unió számára, amelynek értelmében az Európai Uniónak arra kell törekednie, hogy a világ legversenyképesebb és legdinamikusabb tudásalapú gazdasága legyen, amely nagyobb arányú foglalkoztatást, jobb munkahelyeket és erősebb társadalmi kohéziót biztosítva képes a fenntartható növekedésre.

A cél eléréséhez a tudásalapú társadalom követelményeinek megfelelő, a magasabb szintü és színvonalú foglalkoztatás igényét kielégíteni képes oktatási és képzési rendszerekre van szükség. A cél elérése érdekében az Európai Tanács arra szólította fel a tagállamokat, alkossa meg a kulcskompetenciák kereteit és elvárásait. (Európai Közösségek Bizottsága, 2000.)

Előrehaladásukról szóló 2002-es jelentésükben a munkacsoport már bemutatott egy keretrendszert, amely nyolc kulcskompetenciát tartalmazott, köztük a digitális kompetenciát is

1. Az anyanyelven folytatott kommunikáció;

2. Az idegen nyelveken folytatott kommunikáció;

3. Matematikai kompetencia és alapvető kompetenciák a természet- és müszaki tudományok terén;

4. Digitális kompetencia;

5. A tanulás elsajátítása;

6. Szociális és állampolgári kompetenciák;

7. Kezdeményezőkészség és vállalkozói kompetencia, valamint 8. Kulturális tudatosság és kifejezőkészség,

valamint az egyes területekhez tartozó ismereteket, készségeket és attitüdöket is meghatározta.

\section{OECD}

Az Európai Unión kívül, az OECD (Organisation for Economic Co-operation and Development, Gazdasági Együttmüködési és Fejlesztési Szervezet) is elkészítette saját programját 1997-2002 között, DeSeCo (Defining and Selecting Key Competencies) néven. Ez a program az vizsgálta, milyen kulcskompetenciákra 
van szükség a sikeres élethez és a jól müködő társadalom megteremtéséhez, majd meghatározta és strukturálta a kulcskompetencia fogalmát.

A DeSeCo program értelmezése szerint „a kompetencia képesség a komplex feladatok adott kontextusban történö sikeres megoldására”. (OECD, 2005.) A fogalom magában foglalja az ismeretek mobilizálását, a kognitív és gyakorlati képességeket, a szociális és magatartási komponenseket és attitüdöket, az érzelmeket és az értékeket egyaránt. A DeSeCo-program a kulcskompetenciák három területét határozta meg:

1. az autonóm cselekvés;

2. az eszközök interaktív használata;

3. a szociálisan heterogén környezetben való müködés.

\subsection{Európai Parlament, Európai Tanács}

Az Európai Parlament és a Tanács az egész életen át tartó tanuláshoz szükséges kulcskompetenciákról szóló ajánlásának 2006-os publikálása óta a köznevelést meghatározó alapdokumentumok, tantervek és kutatások központi fogalma is a kompetencia lett. A fogalomhasználat mellett fontosabb, hogy az oktatás céljává is a kompetenciák fejlesztése vált. Az ajánlás célja is ez: „az oktatás kettős, társadalmi és gazdasági, szerepéböl adódóan kulcsfontosságú szerepet játszik annak biztositásában, hogy az európai polgárok elsajátitsák az ezekhez a változásokhoz való rugalmas alkalmazkodáshoz szükséges kulcskompetenciákat." (Az Európai Parlament és a Tanács, 2006., old.: 13) A kompetenciákat a dokumentum az adott helyzetben megfelelő ismeretek, készségek és attitüdök ötvözeteként határozta meg. A kulcskompetenciák tehát azok a kompetenciák, amelyekre minden egyénnek szüksége van a személyes önmegvalósításhoz és fejlődéshez, az aktív polgársághoz, a társadalmi beilleszkedéshez és a foglalkoztatáshoz.

Az ajánlásban negyedik számú kulcskompetenciaként kerül kifejtésre a digitális kompetencia, amely kifejtés egyfajta válasz a web 2.0 megjelenése óta kialakuló újmédia készségszintű és biztonságos használata kapcsán megfogalmazott kérdésekre. Körülbelül 2005 óta, a web 2.0 forradalmának köszönhetően az embereknek nincs szükségük különösebben komoly informatikai ismeretre az internetes jelenléthez. A web 2.0 elhozta az úgynevezett ,ír-olvas világhálót”. (Poore, 2015, old.: 32.) Ez az újfajta, huszonegyedik századra kialakult internetes kommunikáció, valamint a webes jelenlét annyira a hétköznapi élet részévé vált, hogy annak szerepe a tanítási-tanulási folyamatokban is megkerülhetetlen lett. 
Külföldi és magyar szakirodalmak egyaránt vizsgálják az online tér, azon belül leggyakrabban a közösségi média hétköznapi életre gyakorolt élettani és pszichológiai hatásait, kiemelve annak oktatásban betöltött szerepét is. A terület jellegéből adódóan folyamatosan változó, és a tanítási-tanulási folyamatban résztvevő minden szereplő hétköznapi életét évről évre jobban meghatározó digitális környezet számtalan feladatot és megközelítési lehetőséget ad a témában mélyebben elmerülő kutatóknak. A 2000-es évek generációja azon a technológián nő fel, amit a szüleik is ismernek, viszont velük ellentétben ők már beleszülettek ebbe a technikai környezetbe, így sokkal könnyebben alakítják kompetenciává elméleti és használati tudásukat. (Tari, 2011)

Marc Prensky ezeket a fiatalokat digitális bennszülötteknek nevezi, akik egész életüket úgy élték le, hogy számítógépek, televíziók, videójátékok, kamerák, mobiltelefonok és a digitális kor egyéb vívmányai vették körül őket, ezért már „anyanyelvi szinten” beszélik az internet digitális nyelvét. Ezekből következik, hogy a mai diákok másképp is gondolkodnak a világról, másképp dolgozzák fel a környezetükből érkező információkat, mint szüleik, vagy tanáraik.

Nem feltétlenül velük szemben, de szinte biztosan az ö világukon kívül helyezkednek el a digitális bevándorlók. (Prensky, 2001) Ök azok, akiknek még idegen az internet világa, és ha információra van szükségük, akkor nem az internet az első gondolatuk, ahonnan az információt beszerezhetik. Prensky szerint az oktatás mai problémái közül az egyik legfontosabb, hogy nagyon sok a digitális bevándorló tanár, akik más nyelvet beszélnek, mint megváltozott tanítványaik, akik már nem azok, akikre a módszereiket kitalálták, és akikre az oktatási rendszert tervezték. A ma diákjai már hozzá vannak szokva, hogy az információkhoz gyorsan hozzá tudnak jutni, szeretnek egyszerre több mindennel foglalkozni, jobban kedvelik az ábrákat, képeket, mint a hosszú szövegeket, valamint igénylik az azonnali visszajelzéseket, megerösítéseket. Ezekhez egyértelmüen a digitális világ szoktatta őket, ebben a világban van szükség a pedagógiai munka minden szereplöjének az adott helyzetben megfelelő ismeretek, készségek és attitüdök ötvözeteként meghatározott kompetenciáinak alkalmazására.

A fentiek következtében a digitális kompetencia fogalmának magyarázata elkerülhetetlen. Ezt többen és többféleképpen meg is tették. Az élethosszig tartó tanuláshoz szükséges kulcskompetenciák referenciakeretét kidolgozó munkacsoport is megalkotta saját fogalommagyarázatát, mely szerint „, a digitális kompetencia magában foglalja az információs társadalmi technológiák (IST) magabiztos és kritikus használatát a munka, a szabadidö és a kommunikáció terén. Ez az IKT terén meglévö alapvetö készségeken alapul: számitógép használata információ visszakeresése, értékelése, tárolása, elóállitása, 
bemutatása és cseréje céljából, valamint a kommunikáció és az együttmüködö hálózatokban való részvétel céljából az interneten keresztül.” (Az Európai Parlament és a Tanács, 2006.)

A kompetenciához kapcsolódó ismereteket, készségeseket és attitüdöt is konkretizál: , Magában foglalja a fö számítógépes alkalmazásokat, mint például a szövegszerkesztést, adattáblázatokat, adatbázisokat, információtárolást és kezelést, valamint az internet által kínált lehetőségek és esetleges veszélyek megértését és az elektronikus média útján történö kommunikációt (e-mail, hálózati eszközök) a munka, a szabadidö, az információ megosztása és az együttmüködö hálózatépités, a tanulás és kutatás számára (...) A szükséges készségek magukban foglalják: az információ megkeresésének, összegyüjtésének és feldolgozásának képességét és kritikus és szisztematikus alkalmazását, értékelve a fontosságát és megkülönböztetve a valóst a virtuálistól a kapcsolatok felismerése során (...) Az IST használata kritikus és megfontolt attitüdöt követel az elérhetö információ és az interaktív média felelösségteljes használata tekintetében. Ezt a kompetenciát támogatja továbbá a kulturális, társadalmi és/vagy szakmai célokat szolgáló közösségekben és hálózatokban való részvétel iránti érdeklődés." (Az Európai Parlament és a Tanács, 2006.)

A 2006-ban készített ajánlásban az alapszintü szoftverhasználat, a kommunikáció, az információk keresése mellett a kritikai gondolkodás és a hálózati szerep a leghangsúlyosabb. Ez a meghatározás még a fentebb már bevezetett újmédia, a közösségi média, valamint a legújabb okos mobilkészülékek elterjedése előtt született, ugyanakkor a hangsúlyos elemei semmit sem veszítettek aktualitásukból és az oktatás számára is fontos relevanciájából.

\subsection{DigComp}

A digitális kompetencia új európai keretrendszere, alkalmazkodva a folyamatosan változó környezethez 2013-ban készült el, DigComp (Digital Competence Framwork for Citizens) néven. A DigComp a digitális kompetencia értelmezésének és fejlesztésének európai referenciakerete, amely a digitális kompetenciák egységes értelmezését teszi lehetővé. (Racskó, 2017)

A keretrendszer öt kompetenciaterületet nevez meg:

1. Információ,

2. kommunikáció,

3. tartalomkészítés,

4. biztonság, 
5. problémamegoldás.

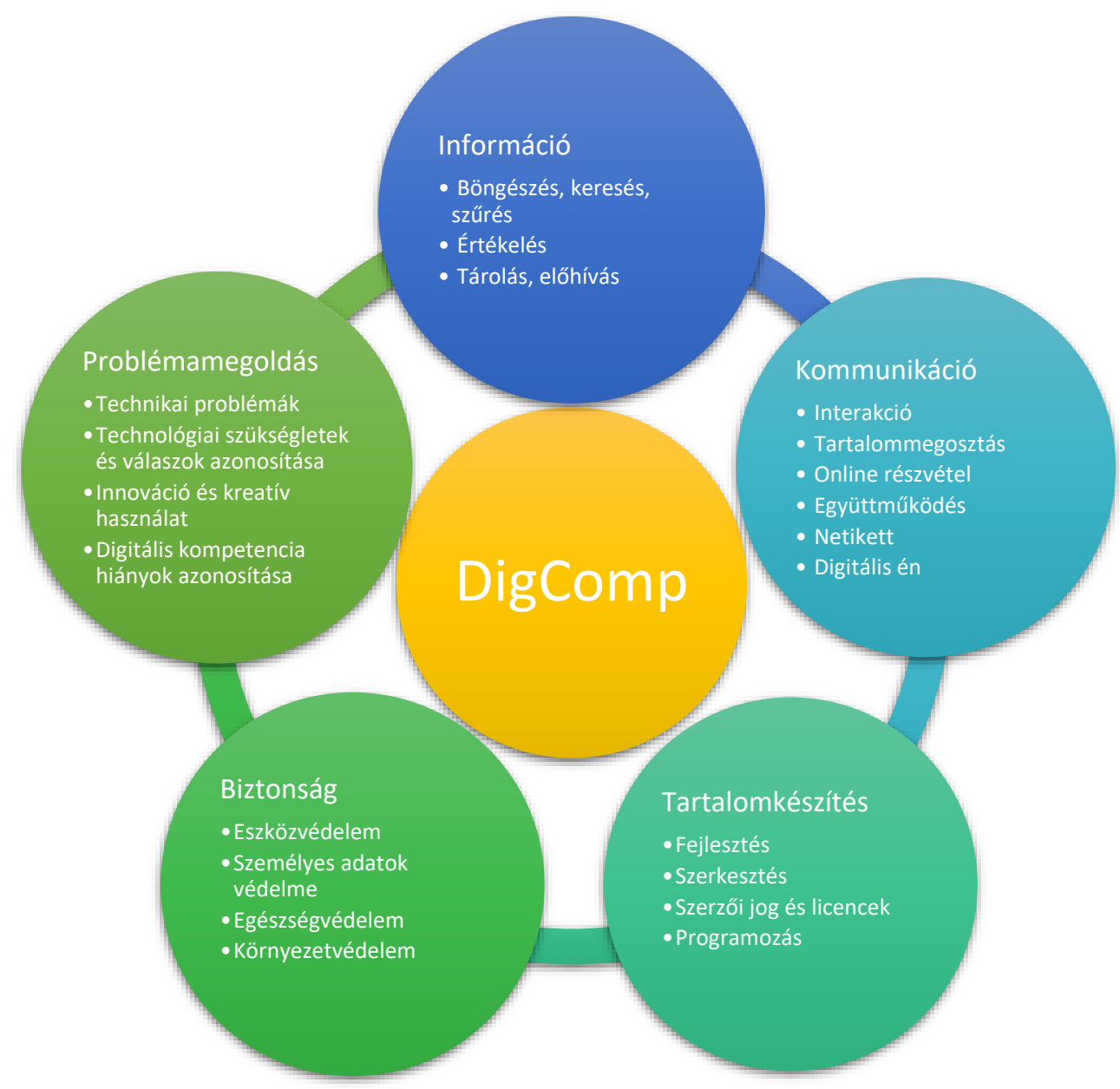

A dokumentum ezeket már, mint a digitális állampolgárság komponenseit azonosította, definiálta, majd további 21 részterületre bontotta.

A továbbiakban mindegyik területet öt dimenzión keresztül mutatja be a dokumentum, illetve a tudás, képesség, attitüd dimenzióin keresztül gyakorlati példákat és alkalmazási lehetőségeket is bemutat. (Ferrari, 2013)

\subsection{DigCompOrg}

Az Európai Unió 2015-ben az oktatási intézmények számára is elkészítette keretrendszerét, amely a DigCompOrg (European Framework for Digitally- 
Competent Educational Organisations) címet kapta. (Kampylis, Punie, \& Devine, 2015) A keretrendszer - hét témakörben - összesen 74 kritériumot ír le az intézményi fejlesztéshez kapcsolódva, célja, hogy támpontot kínáljon az oktatási intézmények szervezetfejlesztéséhez és önértékeléséhez, valamint segítséget nyújtson a szakpolitika számára a helyi, regionális és nemzeti szintü programok és beavatkozások tervezéséhez. A keretrendszer szövegét Hunya Márta fordította magyarra.

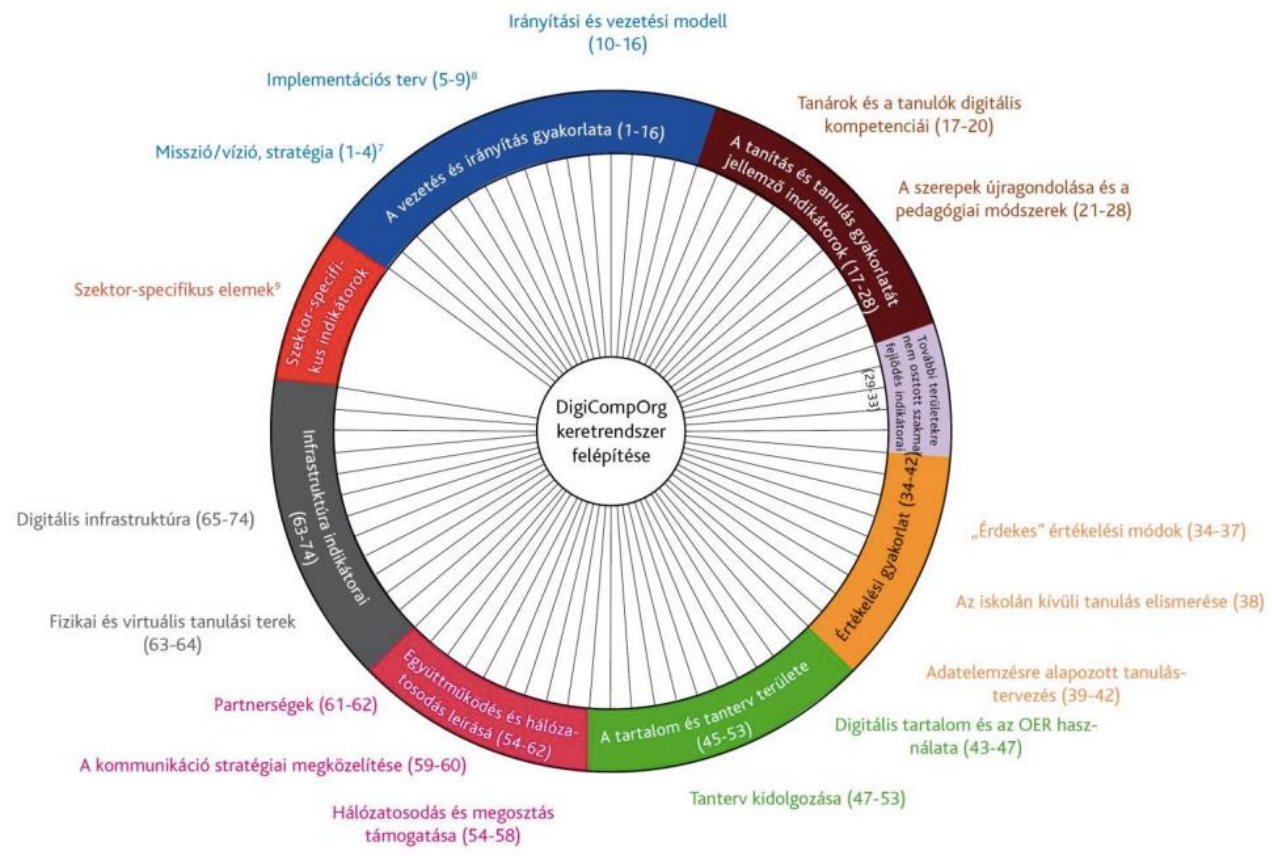

2. Ábra: A DigCompOrg keretrendszer felépítése (Hunya, 2016) 


\section{IKER}

Az IKER (Infokommunikációs Egységes Referenciakeret) egy, a digitális kompetencia önértékelését és fejlesztését támogató referenciakeret, amely több, eltérő felhasználási célra készült dokumentumból áll, célja a digitális kompetencia önértékelésének és fejlesztésének támogatása.

Az IKER kidolgozásánál a Magyar Képesítési Keretrendszer (MKKR) szintezését, valamint az Európai Digitális Kompetencia Referenciakeretet (DIGCOMP), a digitális kompetencia értelmezésének és fejlesztésének európai referenciakeretét (EU Bizottság 26035 N) vették figyelembe. (Rákosi, 2016)

A Kormányzati Informatikai Fejlesztési Ügynökség (KIFÜ) által fejlesztett képzési programok alapvető célja az elsősorban gazdasági szempontból hátrányos helyzetü társadalmi csoportok felzárkóztatása, digitális kompetenciáik fejlesztése annak érdekében, hogy gazdasági versenyképességük növekedjen, munkaeröpiaci esélyeik javuljanak. (Nemzeti Szakképzési és Felnőttképzési Hivatal, 2016)

A „Digitális szakadék csökkentése” - GINOP 6.1.2.-15 címü kiemelt projekt képzései 2016 szeptemberétől indultak, melyet a Nemzeti Szakképzési és Felnőttképzési Hivatal (NSZFH), a Kormányzati Informatikai Fejlesztési Ügynökség (KIFÜ) és a Nemzetgazdasági Minisztérium (NGM) együttmüködésében konzorciumként valósít meg.

Az IKER a digitális kompetenciát négy szintre osztja, amely azt a fejlődési pályát írja le, ezért a magasabb szintek magukba foglalják az alacsonyabbakat. (Praktikus útmutató az IKER referenciakeret használatához, 2017)

1. Megszokott digitális eszközök egyszerü, begyakorolt funkcióit önállóan használja. Újszerü, vagy összetettebb funkciók használatához, vagy ismert funkciók ismeretlen digitális eszközökön való használatához folyamatos iránymutatásra van szüksége.

2. Megszokott digitális eszközt önállóan müködtet, ismert, egymással kapcsolatban lévő funkcióit, több lépésből álló mủveletsorral önállóan használja.

A feladatok megoldása során alkalmanként felmerülő vagy összetett intézkedéseket igénylő helyzetekben pontos iránymutatásra van szüksége.

3. Komplex feladatok ellátásához önállóan választja ki a megfelelö, megszokott digitális eszközöket, amelyek bonyolultabb funkcióit használja. 
4. Ismeretlen digitális eszközt vagy újszerü intézkedéseket igénylő helyzetekben útmutatásra van szüksége.

5. Új ismeretek önálló megszerzését is igénylő feladathelyzetekben önállóan, csoportban, vagy kisebb csoport irányítójaként jár el.

6. Olyan problémahelyzetekben, amelyek megoldásához széles körü, rendszerbe szerveződő elméleti és gyakorlati ismeretekre, azok egyedi és komplex alkalmazására van szükség, útmutatásra van szüksége.

Az IKER referenciakerete tehát tartalmazza a digitális kompetenciák szintjeit, az ezeken belül elvárt kompetenciaterületeket, elvárt készségeket és azok szintjeit, illetve rendelkezik a végrehajtásban szerepet játszó intézményrendszerről, felelösségi körökről is.

Cél az erős központi koordináció megteremtése a digitális kompetenciák és elvárások szabványosítása, a végrehajtást és a tömeges képzést lehetővé tévő intézményrendszer és infrastruktúra - például tananyagok, képzési koncepciók, online vizsgarendszer - kialakítása révén.

Ennek érdekében a DigComp-hoz igazodva a digitális kompetencián belül öt részterületet határoz meg az alábbi fő tartalmi elemekkel:

1. Információ gyüjtése, felhasználása, tárolása: digitális információk beazonosítása, megtalálása, válogatása, tárolása, rendszerezése és elemzése, a cél és relevancia eldöntésével.

2. Digitális, internet alapú kommunikáció: kommunikáció digitális környezetben, információ megosztása online eszközökkel, kapcsolat és együttmüködés másokkal digitális eszközök segítségével, részvétel és közremüködés közösségekben és hálózatokban, a különböző kultúrák lehetséges eltéréseinek figyelembevétele.

3. Digitális tartalmak létrehozása: új tartalom létrehozása és szerkesztése (szöveges dokumentumok, képek, video), meglévő tudás és tartalom beépítése és átdolgozása, kreatív kifejezésmód alkalmazása, médiaelemek létrehozása, programozás, a szerzői jogi vonatkozások figyelembevétele és alkalmazása.

4. Problémamegoldás, gyakorlati alkalmazás: digitális erőforrások és igények beazonosítása, megalapozott döntéshozatal arról, hogy az adott célhoz és igényhez melyik digitális eszköz választása a legmegfelelőbb, elvi problémák digitális megoldása, a technológia kreatív felhasználása, 
technikai problémák elhárítása, saját és mások kompetenciáinak frissítése.

5. IKT biztonság: személyes biztonság, adatvédelem, digitális identitás védelme, biztonsági intézkedések, biztonságos és fenntartható felhasználás.

\subsection{DigComp 2.0}

A DigComp keretrendszer igyekszik megfelelni a folyamatosan változó környezetnek, ezért 2016-ban elkészült az új változata, a DigComp 2.0. (Vuorikari, Punie, Carretero, \& Van den Brande, 2016) Mindössze néhány elemmel bővült az első keretrendszer, de a változások okai a technológia további fejlődése, a digitalizáció előrehaladása és az ezekből következő társadalmi változások lehettek. A keretrendszer szerkezete megmaradt, de a tartalma konkrétabb és bővebb lett, illetve kiegészül a kompetenciaelemek jártassági szintjeivel is. Az első verzióhoz képest az alábbi struktúra szerint épül fel a DigComp 2.0 keretrendszere:

A DigCom 2.0 kibővítette a kompetenciaterületeket, eszerint a frissebb keretrendszer információs- és adatműveltséget, kommunikációt és együttműködést, illetve digitális tartalomfejlesztést határoz meg, míg elődjében a szükebb információ, kommunikáció és tartalomfejlesztés meghatározást használta.

Az elnevezésen túl tartalmi különbségek is felfedezhetők a két keretrendszer között, ezeket a DigComp 2.0 dokumentum részletesen, táblázatba szerkesztve állítja egymással párhuzamba.

\subsection{DigComp 2.1}

Az DigComp 2.0 frissítése 2017-ben készült el, DigComp 2.1 címen, középpontjában az eredeti három ismeretszint kibővítése áll, amelyet egy sokkal kifinomultabb, példákkal kiegészített nyolcszintes rendszer vált fel. Ennek célja, hogy a DigComp további alkalmazásait megismertesse a különböző szereplőkkel. 
A nyolc szint az alapoktól a legmagasabb fokig vázol fel példákat mindegyik kompetenciaterületre és azok részterületeire. A DigComp első verziója az alapokat, a közepes és a fejlett szinteket különböztette meg, és írta le a példákkal a különböző kompetenciaterületeket, a DigComp 2.1 mindegyik szintet kibővítette két részre, és bevezette a legmagasabb, rendkívül specializált szintet. (Carretero, Vuorikari, \& Yves, 2017)
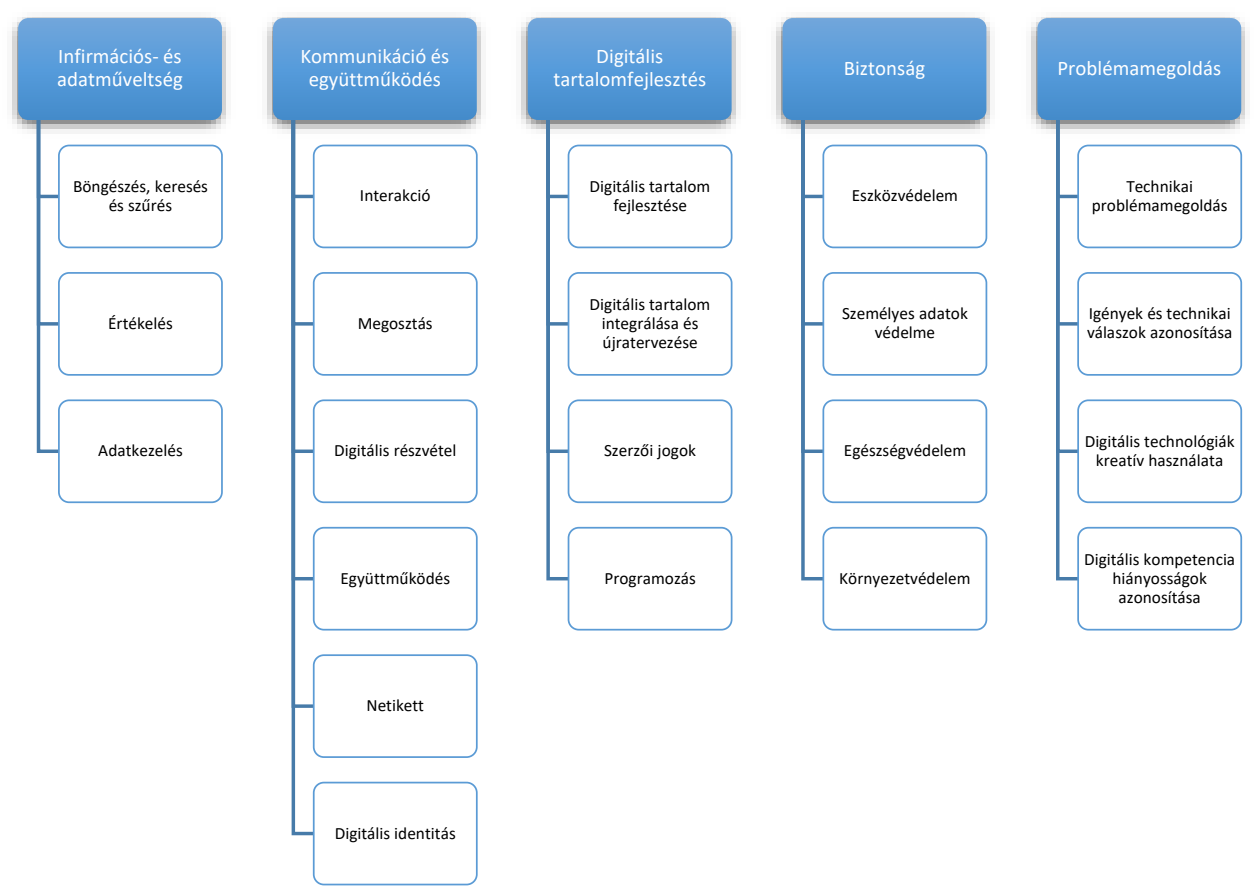

\begin{tabular}{|c|c|c|c|c|}
\hline $\begin{array}{l}\text { DigComp } \\
1.0\end{array}$ & $\begin{array}{l}\text { DigComp } \\
2.1\end{array}$ & $\begin{array}{l}\text { Feladatok } \\
\text { összetettsége }\end{array}$ & Önállóság & Megismerés \\
\hline \multirow[t]{2}{*}{ Alapok } & 1 & $\begin{array}{l}\text { Egyszerü } \\
\text { feladatok }\end{array}$ & Útmutatással & Emlékezet \\
\hline & 2 & $\begin{array}{l}\text { Egyszerü } \\
\text { feladatok }\end{array}$ & $\begin{array}{l}\text { Önállóan, és } \\
\text { útmutatással } \\
\text { ott, ahol } \\
\text { szükséges }\end{array}$ & Emlékezet \\
\hline $\begin{array}{l}\text { Közepes } \\
\text { szint }\end{array}$ & 3 & $\begin{array}{l}\text { Jól } \\
\text { meghatározott és } \\
\text { rutinfeladatok, } \\
\text { egyértelmű } \\
\text { problémák }\end{array}$ & Egyedül & Megértés \\
\hline
\end{tabular}




\begin{tabular}{|c|c|c|c|c|}
\hline & 4 & $\begin{array}{l}\text { Feladatok, jól } \\
\text { definiált } \\
\text { problémák, } \\
\text { nem definiált } \\
\text { problémák }\end{array}$ & $\begin{array}{l}\text { Önállóan, } \\
\text { igényeim } \\
\text { szerint }\end{array}$ & Megértés \\
\hline \multirow[t]{2}{*}{$\begin{array}{l}\text { Fejlett } \\
\text { szint }\end{array}$} & 5 & $\begin{array}{l}\text { Különféle } \\
\text { feladatok és } \\
\text { problémák }\end{array}$ & $\begin{array}{l}\text { Mások } \\
\text { irányítása }\end{array}$ & Alkalmazás \\
\hline & 6 & $\begin{array}{l}\text { Legmegfelelőbb } \\
\text { feladatok }\end{array}$ & $\begin{array}{l}\text { Összetett } \\
\text { környezetben } \\
\text { képes } \\
\text { alkalmazkodni } \\
\text { másokhoz }\end{array}$ & Alkalmazás \\
\hline \multirow[t]{2}{*}{$\begin{array}{l}\text { Rendkívül } \\
\text { specializált } \\
\text { szint }\end{array}$} & 7 & $\begin{array}{l}\text { Összetett } \\
\text { feladatok } \\
\text { megoldása } \\
\text { korlátozott } \\
\text { megoldásokkal }\end{array}$ & $\begin{array}{l}\text { Tudás } \\
\text { beépítése, } \\
\text { hogy az } \\
\text { igazodjon a } \\
\text { gyakorlathoz, } \\
\text { és irányt } \\
\text { mutasson } \\
\text { másoknak }\end{array}$ & Alkotás \\
\hline & 8 & $\begin{array}{l}\text { Összetett } \\
\text { feladatok } \\
\text { megoldása sok } \\
\text { változó } \\
\text { tényezővel }\end{array}$ & $\begin{array}{l}\text { Új ötletek } \\
\text { javaslása az } \\
\text { adott területen }\end{array}$ & Alkotás \\
\hline
\end{tabular}

\subsection{Digitális Kompetencia Keretrendszer}

Az IKER után, és a DigComp 2.1 hatására készülőben van Magyarország új digitális kompetencia keretrendszere, amely megvalósítására 2019. június 11-én fogadtak el kormányhatározatot. (Korm. határozat, 1341/2019.)

A határozat elfogadásának célja, hogy Magyarország minden polgára és vállalkozása a digitalizáció nyertese legyen, valamint a digitális átalakulás során Magyarország Európa legsikeresebb, legjobb teljesítményre képes országai közé tartozzon, illetve az, hogy a digitális felkészültség és kompetenciák hiánya miatt Magyarországon senki ne szoruljon ki a digitális világból és a digitális gazdaságból, továbbá folyamatosan bővüljön a digitálisan felkészült munkavállalók köre. 
Kiemeli a dokumentum, hogy a digitális kompetenciák fejlesztése érdekében a korábbi fejlesztések eredményeire építve egységes digitális kompetencia keretrendszer létrehozása szükséges, ezért kell kidolgozni a Digitális Kompetencia Keretrendszert.

A feladat egy hosszútávú koncepció, amely során kidolgozzák a keretrendszer szervezeti, intézményi, finanszírozási modelljét, valamint megvizsgálják a digitális kompetenciák validálásának és beszámításának eljárásrendjét. A feladat elvégzésének határidejét 2020 júniusára tüzték ki.

A keretrendszer második szintjén fogalmazzák meg a célcsoport-specifikus digitális kompetenciakereteket, amelyek között helyet kap a pedagógus kompetenciakeret is. 


\section{Pedagógusok digitális kompetenciája}

A digitális átalakulás társadalmi és pszichológiai következményei kikerülhetetlenül hatással vannak az oktatás világára. Az előző fejezetben tárgyalt, a digitális kompetenciára általánosságban vonatkozó keretrendszerek mellett nagyon fontos ezek adaptálása a tanítási-tanulási folyamatokra.

A fent már említett digitális bevándorlók és digitális bennszülöttek közötti ellentét lehet az a sztereotípia, hogy a tanár kívülröl jön a diák világába, ezért ott idegenként tekint rá a közösség, pedig valójában a digitális világ, az online tét, az internetes applikációk, vagy a digitális eszközök oktatási célokra való használata még mindig új terület a folyamatban résztvevő mindkét fél számára.

Az általános vélekedés is az, hogy az IKT-eszközök használatának ismerete elegendő a pedagógus számára, holott a fentebb röviden bemutatott keretrendszerek mindegyike ennél jóval összetettebb ismereteket vár el. A digitális tábla, vagy a projektor használata ezen készségek nélkül nem tölt be több szerepet, mint az írásvetítő, vagy a hagyományos osztálytermi tábla.

A kompetencia szemlélet a magyar tanárképzésben a 15/2006-os OM rendelettel vette kezdetét. Ez írta elő előszőr a pedagógus kompetenciákat, de az irány maradt és a következő Nemzeti Alaptantervek is megtartották a kompetenciaközpontú struktúrát. (Szőke-Milinte, 2015)

A pedagóguskompetenciák és a hozzájuk tartozó indikátorok a pedagógus minősítési rendszerben a pedagógus I. illetve a pedagógus II. fokozatba lépéshez segítséget nyújtó útmutatóban kerültek kifejtésre. (Antalné Szabó, és mtsai., 2013)

A dokumentum a 326/2013. (VIII. 30.) Korm. Rendeletnek megfelelően nyolc pedagóguskompetenciát nevez meg:

1. kompetencia: Szakmai feladatok, szaktudományos, szaktárgyi, tantervi tudás.

2. kompetencia: Pedagógiai folyamatok, tevékenységek tervezése és a megvalósításukhoz kapcsolódó önreflexiók.

3. kompetencia: A tanulás támogatása.

4. kompetencia: A tanuló személyiségének fejlesztése, az egyéni bánásmód érvényesülése, a hátrányos helyzetü, sajátos nevelési igényü vagy beilleszkedési, tanulási, magatartási nehézséggel küzdő gyermek, tanuló többi gyermekkel, tanulóval együtt történő sikeres neveléséhez, oktatásához szükséges megfelelő módszertani felkészültség. 
5. kompetencia: A tanulói csoportok, közösségek alakulásának segítése, fejlesztése, esélyteremtés, nyitottság a különböző társadalmi-kulturális sokféleségre, integrációs tevékenység, osztályfőnöki tevékenység.

6. kompetencia: Pedagógiai folyamatok és a tanulók személyiségfejlődésének folyamatos értékelése, elemzése.

7. kompetencia: Kommunikáció és szakmai együttmüködés, problémamegoldás.

8. kompetencia: Elkötelezettség és szakmai felelősségvállalás a szakmai fejlődésért.

A kompetenciák között önállóan nem szerepel digitális kompetencia, a hozzájuk tartozó indikátorok között is csak bizonyos elemei kaptak helyet.

A „szakmai feladatok, szaktudományos, szaktárgyi, tantervi tudás” indikátorai között a digitális anyagok és eszközök ismerete, a „pedagógiai folyamatok, tevékenységek tervezése és a megvalósításukhoz kapcsolódó önreflexiók" kompetencián belül pedig a digitális és online eszközök célszerü használata szerepel.

A harmadik, ,a tanulás támogatása” kompetencia indikátorai között szerepel az IKT-eszközök hatékony használatára való ösztönzés, az ötödik, „a tanulói csoportok, közösségek alakulásának segítése, fejlesztése, esélyteremtés, nyitottság a különböző társadalmi-kulturális sokféleségre, integrációs tevékenység, osztályfönöki tevékenység” kompetencián belül pedig a „követendő mintát mutat a diákoknak a digitális eszközök funkcionális használatának terén" indikátor utal digitális kompetenciára.

Az „elkötelezettség és szakmai felelősségvállalás a szakmai fejlődésért” meghatározású, utolsó kompetencián belül pedig indikátorként jelenik meg a digitális tanagyagokról, eszközökről, az oktatástámogató digitális technológia legújabb eredményeiről való rendszeres tájékozódás, valamint az, hogy a pedagógus konstruktívan szemléli ezen eszközök felhasználhatóságát.

Az Európai Unió a DigCompEdu keretrendszeren belül igyekezett meghatározni a pedagógusok digitális kompetenciáit. (Redecker, 2017) A DigCompEdu az oktatók és tanárok digitális kompetenciájának európai keretrendszere, amely számos európai tagállam egyre növekvő tudatosságára reagál, felismeri, hogy a pedagógusoknak saját szakmájukhoz szükséges digitális kompetenciákra van szükségük annak érdekében, hogy képesek legyenek megragadni a digitális technológiák lehetőségeit az oktatás és az innováció érdekében. 
A dokumentum hat kompetenciaterületet határoz meg, amik a pedagógusok tanítási-tanulási folyamatok irányítása során történő szakmai tevékenységek különbözö aspektusaira összpontosítanak. A kompetenciaterületeket definiálja, illetve további részterületekre bontja.

A Digitális Oktatási Stratégia is felhívja a figyelmet a pedagógusok digitális kompetenciájának fontosságára. Kiemeli azt is, hogy a pedagógus minősítési rendszerben sem kap megfelelö hangsúlyt ez a kompetencia.

A magyar pedagógusok digitális kompetenciájának felmérésére Eszenyiné Borbély Mária végzett kutatást 2018-ban, amely során kérdőívüket 822 fö töltötte ki. A kérdőívet a DigComp keretrendszer szerint állították össze.

„A vizsgálat szerint a pedagógusok legerösebb kompetenciaterületének az információ kompetenciaterület bizonyult. Ezen a kompetenciaterületen a legkisebb az alapszinten állók aránya (16 százalék) és legmagasabb a haladó szinten állóké (42 százalék). Meg kell jegyezni, hogy közepes jártassággal is ugyanilyen arányban rendelkeznek a pedagógusok. Ez az egyetlen kompetenciaterület, ahol a haladó jártassággal rendelkezők vannak a legtöbben. Igen jelentős, a haladókéval megegyező a közepes jártassági szinten állók aránya, 42 százalék.

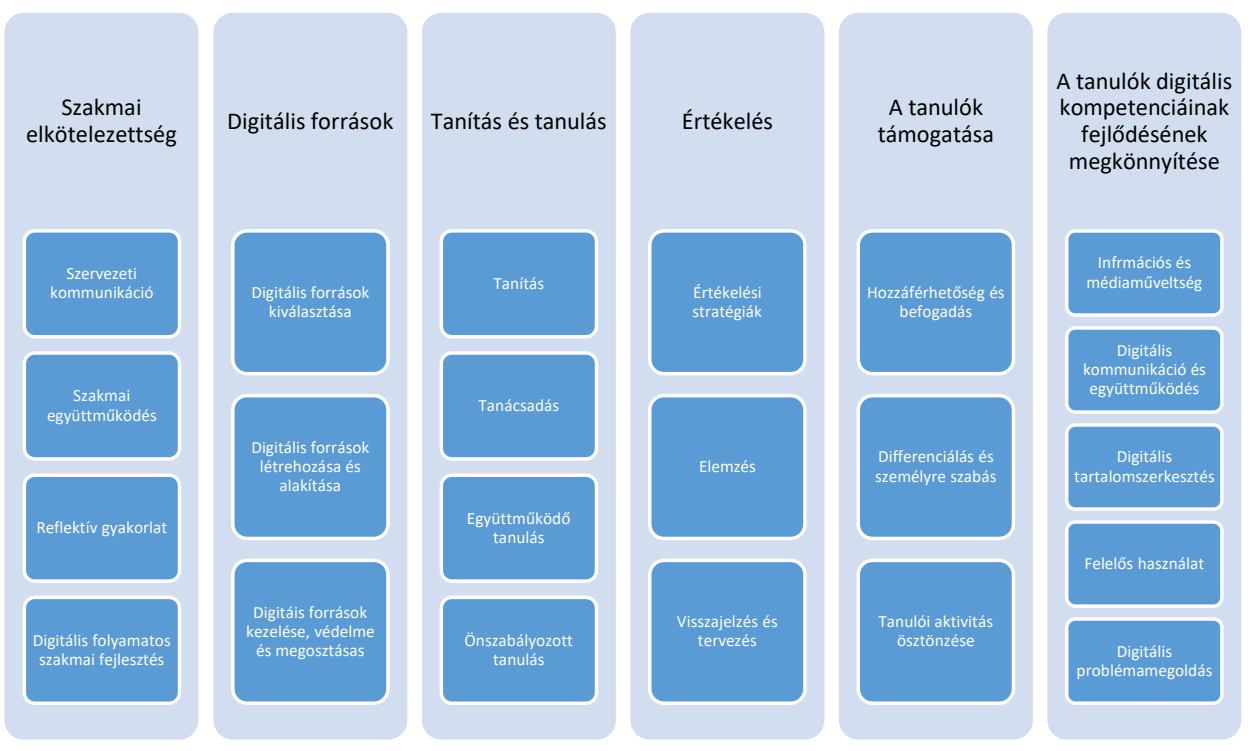

Összességében a pedagógusok nagy tábora áll az információkezelés közepes vagy haladó jártassági szintjén, 84 százalékuk. 
A pedagógusok második legerősebb kompetenciaterülete a digitális környezetben végzett kommunikáció. Az alapszinten állók számaránya jelentősen alacsonyabb, mint a közepes és haladó szinten állóké, de ennek ellenére jelentősnek tekinthető, 28,5 százalék. Ezen a kompetenciaterületen már többen állnak közepes jártassági szinten, mint haladó szinten. (37,5 százalék és 34 százalék), de a két felsőbb szinten állók számaránya még így is elfogadható, 71,5 százalék. A biztonság kompetenciaterület a harmadik legerősebb pedagógus kompetencia a haladó szint aránya szerint rendezve a sort. Ugyanakkor látni kell, hogy ezen a kompetenciaterületen már a csak alapszintü kompetenciával bírók számaránya a legmagasabb (40 százalék), és a legalacsonyabb pedig a haladó szinten állóké (27 százalék).

Összességében a pedagógusok 60 százaléka birtokolja alapszintet meghaladó mértékben a digitális biztonság kompetenciáit. A haladó kompetenciaszint kiterjedtsége szerint (24 százalék) a tartalom-előállítás kompetenciaterület a negyedik a pedagógusok digitáliskompetencia-területeinek sorában. Azonban ezen a területen a legnagyobb az alacsony jártassági szinten állók számaránya (43 százalék). A haladó szinten állók aránya 24 százalék, ami messze elmarad a kívánatos mértéktől, tekintettel arra, hogy a tartalom-előállítás a NAT szerint már a gyerekektől is elvárt készségcsoport. Az alaptanterv többek között elvárja ezen a területen a főbb számítógépes alkalmazások, például a szövegszerkesztést, az adattáblázatok kezelését, és ide tartozik a komplex információ előállítását, bemutatását és megértését elősegítő eszközök használata is. [6] A pedagógusoknak mindössze 57 százaléka képes közepes vagy haladó jártassági szinten tartalmat előállítani. A problémamegoldás kompetenciaterületen a haladó szinten állók aránya a legalacsonyabb a többi kompetenciaterülethez hasonlítva, a közepes szinten állók aránya pedig a legnagyobb. Összességében többen állnak ezen a kompetenciaterületen alapszint felett, 61 százaléknyian, mint a tartalomelőállítás területén.” (Eszenyiné Borbély, 2018)

A szerző szerint a tanulmányban ismertetett vizsgálat eredményei egyértelmüen igazolják, hogy a közoktatásnak, a pedagógusoknak támogatásra van szükségük a tantervi célok megvalósításához a digitális írástudás, kompetenciafejlesztés, és az ehhez kapcsolódó számos további területen is.

Bár a tanulmánynál korábban született a Digitális Oktatási Stratégia, javaslataik mégis összecsengenek. A Digitális Oktatási Stratégiában is megfogalmazott cél, hogy kerüljön pontos meghatározásra a pedagógusok digitális kompetenciáinak kötelezően elvárt szintje a pedagógus életpályán való előrelépéshez, ezzel együtt a magyar tanárok digitális kompetenciaszintje 2020-ra haladja meg az Európai Unió átlagát, valamint teremtsék meg a magyar pedagógusok digitális 
kompetenciájának fejlesztéséhez szükséges anyagi, infrastrukturális és képzési feltételeket. (Digitális Oktatási Stratégia, 2016.)

\section{Folytatás}

Az Európai Unió kifejlesztette a SELFIE (Self-reflection on Effective Learning by Fostering the use of Innovative Educational Technologies) eszközt azért, hogy segítsen beépíteni az iskoláknak a digitális technológiákat a tanításba, a tanulásba és a diákok értékelésébe. Rávilágít, hogy mely területek müködnek jól, melyek szorulnak fejlesztésre, továbbá segít a prioritások meghatározásában.

Az eszköz névtelen formában összegyüjti a diákok, a tanárok és az iskolavezetők meglátásait arra vonatkozóan, hogy miként használják a technológiát az iskolájukban. Ezek felmérése rövid állításokkal, kérdésekkel és egy 1-5-ig terjedő egyetértési skála segítségével történik. Az állítások olyan területeket ölelnek fel, mint például az iskolavezetés, az infrastruktúra, a tanári képzések, valamint a diákok digitális kompetenciája.

2019. február 27-ig 54 magyar iskola regisztrált A SELFIE oldalán, hogy igénybe vegye azt az online önértékelő eszközt. Egy következö kutatásban érdemes lenne ennek az eszköznek a felépítését, a magyar eredmények alapos értékelését elvégezni, bízva abban, hogy az ebben kirajzolódó kép is segít a magyar pedagógusok digitális kompetenciájának szintfelmérésében. 


\section{Irodalomjegyzék}

Tari, A. (2011). Z generáció. Budapest: Tercium.

Carretero, S., Vuorikari, R., \& Yves, P. (2017). DigComp 2.1 The Digital Competence Framework for Citizens. EUR 28558 EN: doi:10.2760/38842.

Nemzeti Szakképzési és Felnőttképzési Hivatal. (2016). Forrás: Nemzeti

Szakképzési és Felnőttképzési Hivatal honlapja:

https://www.nive.hu/index.php?option=com_content\&view=article\&id= 665\#system-message-container (utoldó letöltés: 2020. június 7.)

Digitális Oktatási Stratégia. (2016.). Magyarország Digitális Oktatási Stratégiája. Budapest: Kormány-előterjesztés melléklete.

Szőke-Milinte, E. (2015). A pedagóguskompetenciák megfigyelése és elemzése a tanítási órán. In K. Baditzné Pálvölgyi, É. Szabó, \& R. Szentgyörgyi, Tanóratervezés és tanórakutatás A magyar nyelv és irodalom, az idegen nyelvek és a müvészetek müveltségi területen (old.: 9-27). Budapest: ELTE.

Antalné Szabó, Á., Hámori, V., Kimmel, M., Kotschy, B., Móri, Á., SzőkeMilinte, E., \& Wölfling, Z. (2013). Útmutató a pedagógusok minősitési rendszerében a Pedagógus I. és Pedagógus II. fokozatba lépéshez. Budapest: Oktatási Hivatal.

Az Európai Parlament és a Tanács. (2006. december 30.). Az Európai Parlament és a Tanács ajánlása az egész életen át tartó tanuláshoz szükséges kulcskompetenciákról. Az Európai Unió Hivatalos Lapja, 2006/962/EK(L 394), 10-18.

Eszenyiné Borbély, M. (2018). Pedagógus digitális kompetencia-körkép2018. 1. rész.

Európai Közösségek Bizottsága. (2000.. október 30.). Memorandum az egész élten át tartó tanulásról. SEC(2000) 1832. Brüsszel.

Ferrari, A. (2013). DIGCOMP: A Framework for Developing and Understanding Digital Competence in Europe. Luxembourg: Publications Office of the European Union.

Hunya, M. (2016). A tanulás támogatása a digitális korszakban. A digitálisan kompetens oktatási intézmények európai keretrendszere. In Melléklet a 
digitális és online munkacsoport eredményei címü tanulmányhoz. Budapest: Tempus Közalapítvány.

Kampylis, P., Punie, Y., \& Devine, J. (2015). Promoting Effective Digital-Age Learning - A European Framework for Digitally-Competent Educational Organisations. EUR 27599 EN: doi:10.2791/54070.

Korm. határozat. (1341/2019.. VI. 11.). a Digitális Kompetencia Keretrendszer fejlesztéséről és bevezetésének lépéseiről.

OECD. (2005.). The definition and selection of key competencies. Executive Summary.

Poore, M. (2015). Hogyan használjuk a közösségi médiát az oktatásban? Budapest: Wolters Kluwer.

Praktikus útmutató az IKER referenciakeret használatához. (2017).

Prensky, M. (2001). Digital natives, digital immigrants. On the horizon MCB Universiy Press, P.(5.). https://doi.org/10.1108/10748120110424816

Racskó, R. (2017). Digitális átállás az oktatásban. Budapest: Iskolakultúra, Gondolat. https://doi.org/10.17717/IQKONYV.Racsko.2017

Redecker, C. (2017). European Framework for the Digital Competence of Educators, DigCompEdu. EUR 28775 EN: doi:10.2760/159770 .

Rákosi, S. (2016). Infokommunikációs Egységes Referenciakeret, azaz IKER.

Vuorikari, R., Punie, Y., Carretero, S., \& Van den Brande, L. (2016). DigComp 2.0: The Digital Competence Framework for Citizens. EUR 27948 EN: doi:10.2791/11517. 